\title{
Physiological quality of osmoprimed gherkin seeds ${ }^{1}$
}

\author{
Rodrigo de Góes Esperon Reis ${ }^{2 *}$, Humberto Pereira da Silva², \\ José Maria Gomes Neves ${ }^{3}$ Renato Mendes Guimarães ${ }^{2}$
}

\begin{abstract}
It was aimed to verify the effect of different methodologies of osmopriming on physiological quality of gherkin seeds. Prior, it has been characterized the initial profile of the gherkin seeds. Then, the seeds were osmoprimed in gerboxes containing two blotter papers wetted with osmotic solutions in a volume equal to three times the paper dry weight and kept in BOD at $15{ }^{\circ} \mathrm{C}$. After the priming, the seeds were dried at room temperature for 48 hours. Then, the following variables were evaluated: seeds moisture content, percentage of germination, percentage of emergence, emergence speed index and electrical conductivity. The analyses of variances were realized according to a randomized design in a factorial scheme 3 × 2 × 4: three solutes (polyetilene glycol 6000 - PEG, potassium nitrate $-\mathrm{KNO}_{3}$ and $\mathrm{PEG}+\mathrm{KNO}_{3}$ ), two osmotic potentials (-0.55 and $-1.10 \mathrm{MPa})$ and four times of priming $(24,48,72$ and 96 hours), followed by analyses of regression. It is concluded that the priming has no effect on germination and affects positively the vigor of the gherkin seeds lots; osmopriming with potassium nitrate is effective in improving the physiological quality of gherkin seeds lot.
\end{abstract}

Index terms: Cucumis anguria L., priming, polyetilene glycol, potassium nitrate.

\section{Qualidade fisiológica de sementes de maxixe osmocondicionadas}

\begin{abstract}
RESUMO - Objetivou-se verificar o efeito de diferentes metodologias de condicionamento osmótico sobre a qualidade fisiológica de sementes de maxixe. Inicialmente, foi realizada a caracterização do perfil inicial do lote de sementes. Depois, as sementes foram osmocondicionadas em gerbox contendo duas folhas de papel mata-borrão umedecidas com soluções osmóticas com um volume igual a três vezes o peso seco do papel e mantidas em BOD a $15^{\circ} \mathrm{C}$. Após o condicionamento, as sementes foram secadas em condições ambientais por 48 horas. Em seguida, foram avaliadas as seguintes variáveis: teor de água das sementes, porcentagem de germinação e de emergência, índice de velocidade de emergência e condutividade elétrica. As análises de variâncias foram realizadas de acordo com um delineamento inteiramente casualizado em esquema fatorial 3 x 2 × 4: três solutos (polietileno glicol 6000 - PEG, nitrato de potássio - $\mathrm{KNO}_{3}$ e $\left.\mathrm{PEG}+\mathrm{KNO}_{3}\right)$, dois potenciais osmóticos (-0,55 e -1,10 MPa) e quatro tempos de condicionamento (24, 48, 72 e 96 horas), e em seguida uma análise de regressão. Concluiu-se que o condicionamento osmótico não tem efeito na germinação e afeta positivamente o vigor do lote de sementes de maxixe; o condicionamento osmótico em presença de nitrato de potássio é eficiente em melhorar a qualidade fisiológica do lote de sementes de maxixe.
\end{abstract}

Termos para indexação: Cucumis anguria L., condicionamento fisiológico, polietileno glicol, nitrato de potássio.

\section{Introduction}

The gherkin (Cucumis anguria L., Cucurbitaceae) is an olericultural crop of African origin, which was introduced in Brazil by slaves, and the Northeast and Southeast regions are the most representative of this culture. However, it is still underutilized by the production system, with no statistics (Silva et al., 2008) or standards established for the production and marketing of seeds of this species. In addition, agronomic studies on the culture are scarce (Medeiros et al., 2010).

${ }^{1}$ Submitted on 04/13/2013. Accepted for publication on 05/20/2013. ${ }^{2}$ Departamento de Agricultura, UFLA, Caixa Postal 3037, 37200-000 Lavras, MG, Brasil.
Seed priming is a technique that aims to control the hydration, promoting slower absorption of water and the start of preparatory processes for germination (Santos et al., 2008), especially the biochemical and physiological activities, which will be beneficial for germination, mainly under adverse conditions (Pill et al., 2009). This technique has improved seed vigor of seed lot in different vegetable crops, such as eggplant (Fanan and Novembre, 2007; Nascimento and Lima, 2008; Reis et al., 2012), beetroot (Costa and Villela, 2006), onion (Caseiro et al., 2004), carrot (Balbinot

${ }^{3}$ Departamento de Fitotecnia, UFV, 36570-000 - Viçosa, MG, Brasil. *Corresponding author < guidegoes@gmail.com > 
and Lopes, 2006), pepper (Roveri José et al., 1999; Roveri José et al., 2000), tomato and chili (Venkatasubramanian and Umarani, 2007).

For the gherkin, there are some studies that found improved physiological quality of seed lots after hydropriming (Araújo et al., 2011). The authors comment that this technique has some advantages over the others, for being a simpler, cheaper method and not requiring chemical reagents or sophisticated equipment. However, one disadvantage of this technique may be the fact of the soaking being controlled by the time for which the seeds remain in contact with the water. Thus, each seed reaches a certain stage of the germination process. In contrast, when using osmopriming, soaking occurs more slowly and the most part of seeds reaches the same stage in the process, since soaking is controlled by the osmotic potential of the solution. However, the efficiency of osmopriming is related, among other factors, on the type of solute used, the potential of the solution and priming time.

There are several solutes which are used in the osmopriming of seeds and the most used are polyethylene glycol (PEG) and potassium nitrate $\left(\mathrm{KNO}_{3}\right)$. $\mathrm{PEG}$ is a polymer of high molecular weight, inert, non-toxic and does not penetrate the seeds, due to the big size of its molecules. Nevertheless, there is a reduction of the solubility of oxygen in PEG solutions. The $\mathrm{KNO}_{3}$ does not reduce the availability of oxygen, in addition to benefiting the germination of some species (Ghassemi-Golezani and Esmaeilpour, 2008; Reis et al., 2012).

The potential of the solution is calculated to a value that allows water uptake and realization of the preparatory processes for the seeds germination, but preventing the elongation of the embryo cells, and radicle protrusion, even after a long period of priming (Roveri José et al., 1999) and for each species, there is a solution potential that gives the best results.

Another factor to be noted is the priming time, which should promote soaking of the seed without the occurrence of germination, but ensuring maximum effect of the treatment (Roveri José et al., 2000). Very short times may not provide all the benefits of priming. On the other hand, very long times can damage the quality of seeds, a phenomenon known as "overpriming".

Given the above, we aimed to evaluate the effects of different methods of priming on seeds quality of gherkin.

\section{Materials and Methods}

The experiment was carried out at the Seeds Analysis Laboratory, Federal University of Lavras. Gherkin seeds that remained in cold storage $\left(10{ }^{\circ} \mathrm{C}\right.$ and $\left.55 \% \mathrm{RH}\right)$ until the beginning of the experiment were used.
Prior, it was characterized the initial profile of the seed batch (Table 1). Then the seeds were submitted to priming using gerboxes containing two sheets of blotting paper moistened with the solutions in a volume equivalent to three times the dry weight of the paper, and kept in BOD chamber at $15{ }^{\circ} \mathrm{C}$ and absence of light.

Table 1. Seed moisture content and physiological quality of gherkin seeds before priming.

\begin{tabular}{ccccc}
\hline $\begin{array}{c}\text { Seed moisture } \\
\text { Content }(\%)\end{array}$ & $\begin{array}{c}\text { Germination } \\
(\%)\end{array}$ & $\begin{array}{c}\text { Emergence } \\
(\%)\end{array}$ & ESI & $\begin{array}{c}\text { EC } \\
\left(\mu \mathrm{S} \cdot \mathrm{cm}^{-1} \cdot \mathrm{g}^{-1}\right)\end{array}$ \\
\hline 15.63 & 84 & 24 & 1.7 & 24.57 \\
\hline
\end{tabular}

The osmotic potential of the PEG and $\mathrm{KNO}_{3}$ solutions were calculated according to the equation proposed by Michel and Kaufmann (1973) and Van't Hoff's formula (Hillel, 1971). The PEG $+\mathrm{KNO}_{3}$ solution was obtained by a mixture in the ratio of $1: 1(\mathrm{v} / \mathrm{v})$ of each solution.

After priming, the seeds were washed and dried at room temperature and relative humidity for 48 hours. Then, the following evaluations were performed: seed moisture content: two samples of $0.2 \mathrm{~g}$ of seeds were used for each treatment, placed in an oven at $105 \pm 3{ }^{\circ} \mathrm{C}$ for 24 hours (Brasil, 2009); germination: conducted with four replications of 50 seeds for each treatment sown in gerboxes with two sheets of blotting paper moistened with a volume of water equal to twice the weight of the paper and kept in BOD with a photoperiod of 8 hours and alternating temperatures $\left(30 / 20^{\circ} \mathrm{C}\right)$, accounting for the percentage of normal seedlings after eight days (Brasil, 2009); seedling emergence: made with four replications of 50 seeds sown in trays containing sand and soil $(2: 1 \mathrm{v} / \mathrm{v})$ moistened with water to $60 \%$ of the holding capacity of the substrate and kept in a growth chamber at $25^{\circ} \mathrm{C}$ and a photoperiod of 8 hours, accounting for the percentage of normal seedlings emerged after 21 days; emergence speed index (ESI): held in conjunction with the emergence test, normal seedlings emerged were recorded daily and the index was calculated according to the formula proposed by Maguire (1962); electrical conductivity (EC): there were four replications of 50 seeds per treatment immersed in $50 \mathrm{~mL}$ of deionized water for 24 hours at $25^{\circ} \mathrm{C}$. Next, the electrical conductivity of soaking water was determined through a conductivimeter and the results were expressed in $\mu \mathrm{S} . \mathrm{cm}^{-1} \cdot \mathrm{g}^{-1}$.

The statistical design was a completely randomized design with treatments arranged in a factorial $3 \times 2 \times 4$ : three solutes (polyethylene glycol 6000 - PEG, potassium nitrate $\mathrm{KNO}_{3}$ and $\left.\mathrm{PEG}+\mathrm{KNO}_{3}\right)$, two osmotic potentials ( -0.55 and $-1.10 \mathrm{MPa})$ and four priming times $(24,48,72$ and 96 hours). Data were subjected to analysis of variance and regression, 
splitting the priming time factor within combinations between the solute and potential factors.

\section{Results and Discussion}

On Table 1 are the data for the initial profile of the gherkin seed batch used in this essay. It was verified that the batch used comprises $84 \%$ of germination, but the vigor rates are very low. Thus, it is likely that the use of a pre-germination treatment such as priming improves the quality of the seed batch.

In Table 2 are presented the seed moisture contents of the gherkin seeds dried in environmental conditions after the priming.

It was found that a percentage of germination of seeds primed with PEG at $-0.55 \mathrm{MPa}$ behaved as cubic (Figure 1A), leaving from $78 \%$ germination after 24 hours of priming, achieved approximately $86 \%$ after 42 hours, followed by

gradual reduction. In turn, for the potential of $-1.10 \mathrm{MPa}$ (Figure 1B), the germination was maintained at $84 \%$ at all priming times.

Table 2. Seed moisture content of gherkin seeds submitted to physiological priming using three solutes in two osmotic potentials in four times, after drying in environmental conditions for 48 hours.

\begin{tabular}{lcrrrr}
\hline \multirow{2}{*}{ Solute } & Potentials & \multicolumn{4}{c}{ Time (hours) } \\
\cline { 3 - 6 } & $(\mathrm{MPa})$ & \multicolumn{1}{c}{24} & \multicolumn{1}{c}{48} & \multicolumn{1}{c}{72} & \multicolumn{1}{c}{96} \\
\hline \multirow{2}{*}{$\mathrm{PEG}$} & -0.55 & 11.76 & 11.81 & 9.38 & 9.01 \\
& -1.10 & 9.19 & 11.11 & 11.11 & 12.92 \\
\hline \multirow{2}{*}{$\mathrm{KNO}_{3}$} & -0.55 & 14.71 & 11.76 & 6.25 & 11.44 \\
& -1.10 & 11.76 & 12.13 & 12.13 & 11.76 \\
\hline \multirow{2}{*}{$\mathrm{PEG}+\mathrm{KNO}_{3}$} & -0.55 & 9.38 & 9.01 & 11.76 & 9.01 \\
& -1.10 & 9.38 & 6.07 & 5.88 & 11.11 \\
\hline
\end{tabular}

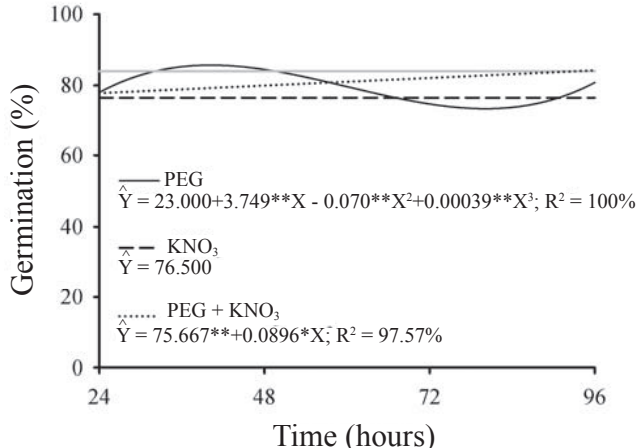

(A)

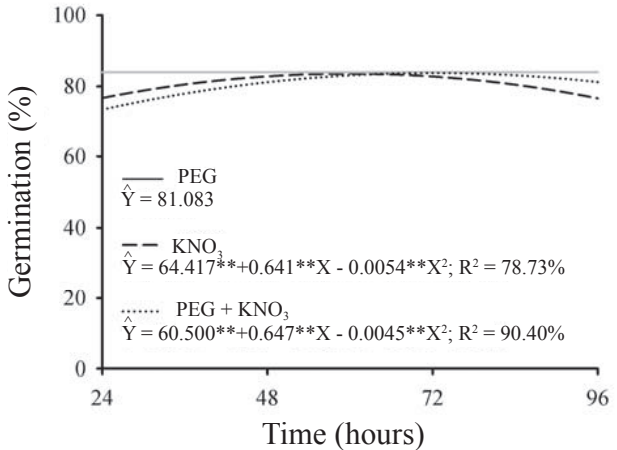

(B)

Figure 1. Percentage of germination of gherkin seeds submitted to priming using three solutes at $-0.55 \mathrm{MPa}(\mathrm{A})$ and $-1.10 \mathrm{MPa}$ (B). The gray line represents the percentage of germination of seeds before priming.

When $\mathrm{KNO}_{3}$ was used at $-0.55 \mathrm{MPa}$ (Figure 1A), the germination was maintained around $77 \%$. While at $-1.10 \mathrm{MPa}$ (Figure 1B), a quadratic fit was found, reaching a maximum of $83 \%$ germination after about 60 hours of priming.

For the combination of $\mathrm{PEG}+\mathrm{KNO}_{3}$ at $-0.55 \mathrm{MPa}$ (Figure $1 \mathrm{~A})$, there was an increasing linear behavior, starting at $76 \%$ and reaching 84\% germination, after 24 and 96 hours of priming. For $\mathrm{KNO}_{3}$ at $-1.10 \mathrm{MPa}$ (Figure 1B), the germination percentage was better adjusted to a quadratic model, peaking at $84 \%$ after about 72 hours of priming.

In general, it was found that in the two potentials studied, the values were around $80 \%$, which does not differ much from unprimed seeds, which showed 84\% germination (Table 1). Therefore, it can be inferred that priming did not impair the viability of gherkin seeds. However, the germination test should be used only to verify that there was no loss in germination, this test is not a good indicator of the efficiency of priming, since seeds with similar viability, but with different levels of vigor, cannot be differentiated by the germination test.

Evaluating the percentage of emergence (Figure 2), it was observed that in the two potentials $(-0.55 \mathrm{MPa}$ and $-1.10 \mathrm{MPa}$ ) the values were above that found for the seeds before priming, which was $24 \%$ (Table 1 ). It is also evident that the PEG solution showed to be inferior to the other two solutions used. At $-0.55 \mathrm{MPa}$ (Figure 2A), there was an increasing linear behavior, starting at about $40 \%$ after 24 hours of priming and reaching 77\% emergence after 96 hours. For the potential -1.10 MPa (Figure 2B), there was an adjustment to a model of the third grade, from $32 \%$ after 24 hours of treatment and after about 80 hours, we calculated an average of $53 \%$ emergence, followed by a decreasing until $43 \%$ after 96 hours of priming.

For $\mathrm{KNO}_{3}$ at $-0.55 \mathrm{MPa}$ (Figure 2A) there was an increased linear behavior with means equal to $59 \%$ after 
24 hours of priming, and reaching $80 \%$ after 96 hours. For the potential $-1.10 \mathrm{MPa}$ (Figure 2B), there was a quadratic adjustment, reaching the maximum percentage of emergence $(80 \%)$ after about 80 hours of priming.

When PEG $+\mathrm{KNO}_{3}$ were used, a quadratic adjustment was found for both potentials. However, there was a greater increase in the emergence percentage in less time when the priming was conducted at $-1.10 \mathrm{MPa}$ (Figure 2B) than at $-0.55 \mathrm{MPa}$ (Figure 2A). In both potential, the seeds started at approximately $40 \%$ emergence after 24 hours of priming. However, at $-0.55 \mathrm{MPa}$, the seeds had to be conditioned more than 80 hours to reach approximately $80 \%$ emergence. At $-1.10 \mathrm{MPa}$, in order to reach the same value, the seeds required less than 70 hours of treatment.

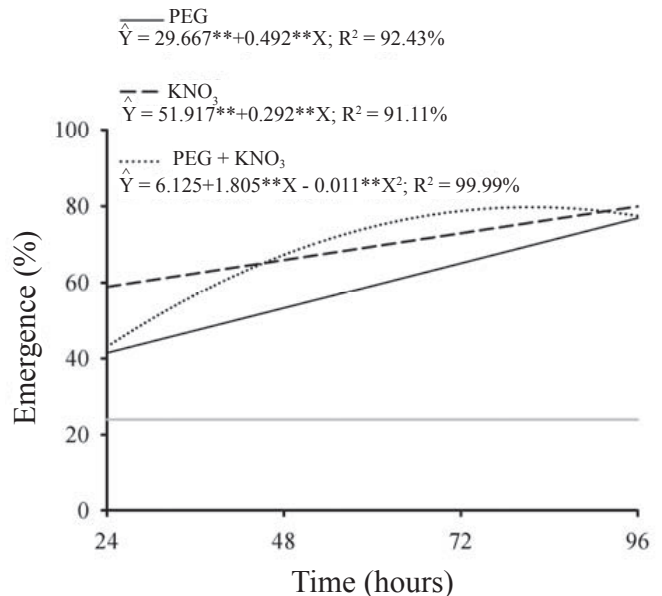

(A)

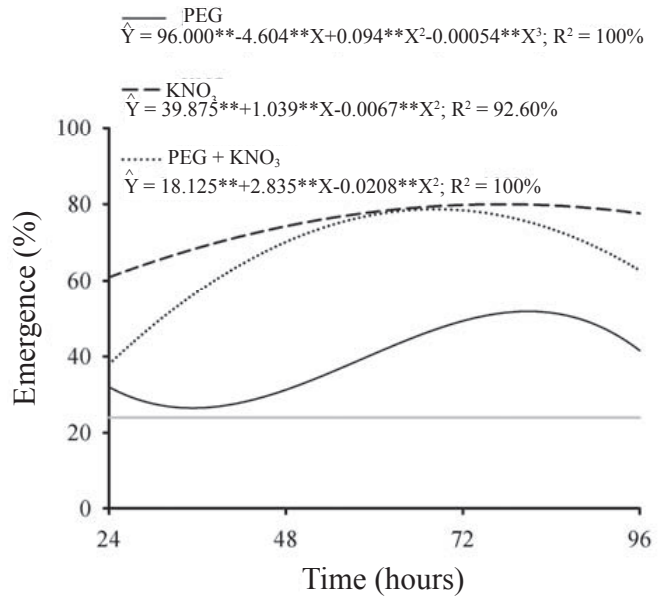

(B)

Figure 2. Percentage of emergence of gherkin seeds submitted to priming using three solutes at $-0.55 \mathrm{MPa}(\mathrm{A}) \mathrm{e}-1.10 \mathrm{MPa}$ (B). The gray line represents the percentage of emergence of seeds before priming.

By the emergence speed index (Figure 3), there are once again gains in seed vigor after priming, compared to the value found initially, that was 1.7 (Table 1). The results for the -0.55 $\mathrm{MPa}$ potential were better than those found to $-1.10 \mathrm{MPa}$.

The seeds primed in PEG, in both potentials, had presented inferior performances to those verified for the other solutions. At $-0.55 \mathrm{MPa}$ (Figure 3A), we observed a quadratic behavior with increments in the emergence speed index throughout the range studied, going from 3.12 and reaching 6.88 after 24 and 96 hours of priming. For the potential $-1.10 \mathrm{MPa}$ (Figure 3B), the best adjustment was found for a third-degree polynomial, starting at 2.53, reaching a maximum 4.57 after approximately 80 hours of priming, decreasing after that.

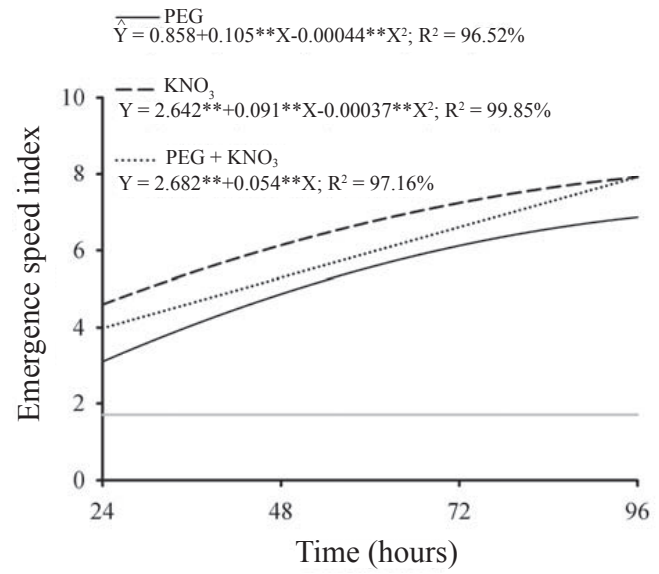

(A)

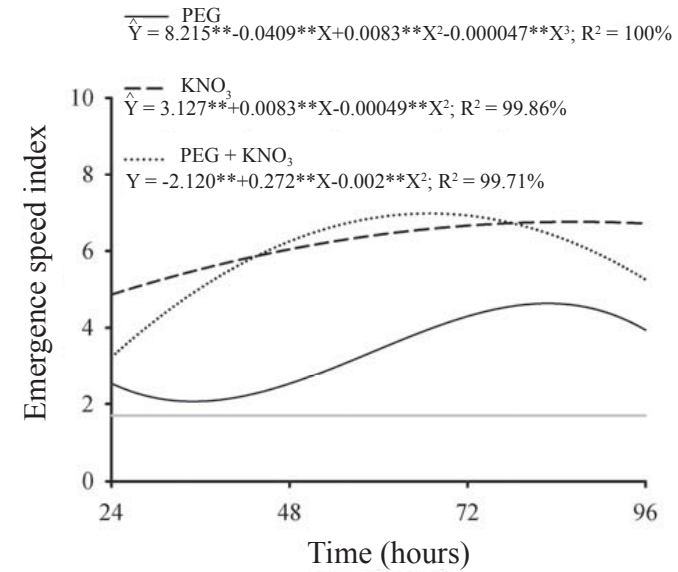

(B)

Figure 3. Emergence speed index of gherkin seeds submitted to physiological priming using three solutes at a $-0.55 \mathrm{MPa}$ (A) e -1.10 MPa (B). The gray line represents the Emergence Speed Index of germination of seeds before priming. 
For seeds primed in $\mathrm{KNO}_{3}$ solution, there was a quadratic behavior in both potentials. However, the increase in vigor after priming in the potential of $-0.55 \mathrm{MPa}$ (Figure $3 \mathrm{~A}$ ) was higher than that verified for potential $-1.10 \mathrm{MPa}$ (Figure 3B). In the first one, the seeds started at 4.61 and reached 7.97, after 24 and 96 hours of priming. In the second one, the emergence speed index started at 4.83 and reached 6.58 , considering the same times mentioned above. There was an increase by $72.9 \%$ and $36.2 \%$ in the emergence speed index after priming for 96 hours in relation to the time of 24 hours, at potentials $-0.55 \mathrm{MPa}$ and $-1.10 \mathrm{MPa}$, respectively. In relation to the value found in the characterization of the initial profile of the seeds, 1.7 (Table 1), these gains were much more expressive: $368.8 \%$ and $287.1 \%$, respectively.

In the priming with $\mathrm{PEG}+\mathrm{KNO}_{3}$ at $-0.55 \mathrm{MPa}$ (Figure $3 \mathrm{~A})$, there was an increasing linear behavior with a emergence speed index equal to 3.98 after 24 hours, reaching 7.87 after 96 hours of priming. For the potential $-1.10 \mathrm{MPa}$ (Figure 3B), there was greater adjustment to a quadratic model, reaching a maximum of 7.13 after 68 hours of priming.

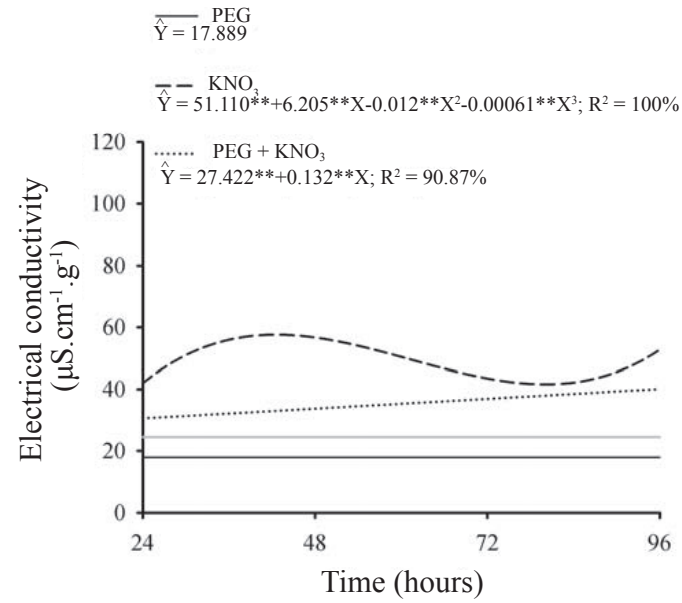

(A)
By the results of percentage and emergence speed index (Figures 2 and 3), it could be observed that the use of potassium nitrate favored seedling vigor. Similar results were obtained by Ghassemi-Golezani and Esmaeilpour (2008) and Reis et al. (2012), in which $\mathrm{KNO}_{3}$ contributed significantly to the invigoration of seedlings of cucumber and eggplant, respectively.

Trigo et al. (1999) commented that the advantage of priming using $\mathrm{KNO}_{3}$ may be related to the fact that it acts as an additional source of potassium and nitrogen during seed germination. Other authors reported that nitrate combined with environmental factors, such as light and temperature, can stimulate the synthesis of gibberellins and favor germination (Saini et al., 1985; Hilhorst et al., 1986), but the sensitivity to these factors varies according to species (Luna and Moreno, 2009).

For electrical conductivity (Figure 4), it was observed that, for the two potentials studied, the seeds primed in PEG exhibited the lowest average, even lower than that found before treatment, $24.57 \mu \mathrm{S} . \mathrm{cm}^{-1} \cdot \mathrm{g}^{-1}$ (Table 1). It can be inferred that there has been a reorganization of the membrane system, which contributed to the reduction of the electrical conductivity.

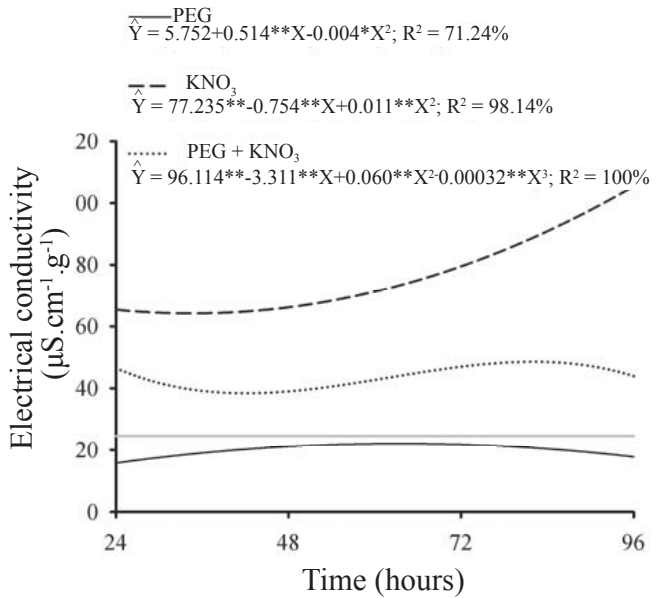

(B)

Figure 4. Electrical conductivity of gherkin seeds submitted to physiological priming using three solutes at $-0.55 \mathrm{MPa}$ (A) e $-1.10 \mathrm{MPa}(\mathrm{B})$. The gray line represents the percentage of Electrical Conductivity of seeds before priming.

In the seeds primed in $\mathrm{KNO}_{3}$ at $-0.55 \mathrm{MPa}$ (Figure 4A), a cubic behavior was observed, with an initial increase, which can be due to absorption of ions $\mathrm{K}^{+}$and $\mathrm{NO}_{3}^{-}$, which are dissociated in solution. Then there was a reduction in the values of electrical conductivity, which can be associated with the reorganization of the membrane system. For the potential $-1.10 \mathrm{MPa}$, there was greater adjustment to a quadratic model, and electrical conductivity increased the growing rates during priming. This behavior may be related to the higher concentration of salt in the $\mathrm{KNO}_{3}-1.10 \mathrm{MPa}$ solution.

When PEG $+\mathrm{KNO}_{3}$ were used, it was observed that electrical conductivity values were intermediate to those found for the other two solutions, at both potentials. For $-0.55 \mathrm{MPa}$ (Figure 4A), the electrical conductivity was better adjusted to an increasing linear model over the range studied, from 30.59 $\mu \mathrm{S} . \mathrm{cm}^{-1} \cdot \mathrm{g}^{-1}$ and reaching $40.09 \mu \mathrm{S} . \mathrm{cm}^{-1} \cdot \mathrm{g}^{-1}$ after 24 and 96 hours of priming. For $-1.10 \mathrm{MPa}$ (Figure 4B), a cubic behavior was found, but they remained between 40 and $50 \mu \mathrm{S} . \mathrm{cm}^{-1} \cdot \mathrm{g}^{-1}$.

The highest values found for electrical conductivity of seeds primed in $\mathrm{KNO}_{3}$ and $\mathrm{PEG}+\mathrm{KNO}_{3}$ is due to the entry of ions in the tissues of the seeds, that were leached for the soaking water during the test, raising the values of this variable. 
The results observed in this study confirm those found by Roveri José et al. (1999), who found in peppers that seeds primed with PEG had lower electrical conductivity than those primed in $\mathrm{KNO}_{3}$. These same authors comment that electrical conductivity has been proposed for the evaluation of seed vigor, being related to the integrity of membranes, but that it is not recommended to consider only the leachate detected in the soaking solution.

It was verified that increments in gherkin seed vigor occur after physiological priming and of $\mathrm{KNO}_{3}$ and $\mathrm{PEG}+\mathrm{KNO}_{3}$ solutions gave better results. However, in the potential -0.55 $\mathrm{MPa}$, both solutions, $\mathrm{KNO}_{3}$ and $\mathrm{PEG}+\mathrm{KNO}_{3}$, can be used for 96 hours. In the potential $-1.10 \mathrm{MPa}$, the $\mathrm{KNO}_{3}$ solution can be used for 96 hours, but seeds primed in PEG $+\mathrm{KNO}_{3}$ expressed the best results after 72 hours of treatment.

\section{Conclusions}

Osmotic priming has no effect on germination and affects positively the vigor of gherkin seeds lot.

Osmopriming with potassium nitrate $\left(\mathrm{KNO}_{3}\right.$ and $\mathrm{PEG}+$ $\mathrm{KNO}_{3}$ ) is effective in improving the physiological quality of the gherkin seeds lot.

\section{References}

ARAÚJO, P.C.; TORRES, S.B.; BENEDITO, C.P.; PAIVA, E.P. Condicionamento fisiológico e vigor de sementes de maxixe. Revista Brasileira de Sementes, v.33, n.3, p.482-489, 2011. http://www.scielo.br/scielo.php?script=sci_arttext\&pid=S0101$31222011000300011 \& \operatorname{lng}=\mathrm{pt} \& \mathrm{nrm}=\mathrm{iso} \& \mathrm{t} \operatorname{lng}=\mathrm{pt}$

BALBINOT, E.; LOPES, H.M. Efeitos do condicionamento fisiológico e da secagem na germinação e no vigor de sementes de cenoura. Revista Brasileira de Sementes, v.28, n.1, p.1-8, 2006. http://www.scielo.br/scielo.php?script=sci arttext\&pid=S0101-31222006000100001\&lng=pt\&nrm=iso\&tlng=pt

BRASIL. Ministério da Agricultura, Pecuária e Abastecimento. Regras para análise de sementes. Ministério da Agricultura, Pecuária e Abastecimento. Secretaria de Defesa Agropecuária. Brasília: MAPA/ACS, 2009. 395p. http:// www.bs.cca.ufsc.br/publicacoes/regras $\% 20$ analise $\% 20$ sementes.pdf

CASEIRO, R.; BENNETT, M.A.; MARCOS-FILHO, J. Comparison of three priming techniques for onion seed lots differing in initial seed quality. Seed Science and Technology, v.32, n.2, p.365-375, 2004.

COSTA, C.J.; VILLELA, F.A. Condicionamento osmótico de sementes de beterraba. Revista Brasileira de Sementes, v.28, n.1, p.21-29, 2006. http://www. scielo.br/scielo.php?script=sci_arttext\&pid=S0101-31222006000100004\&lng $=$ pt\&nrm=iso\&tlng $=\mathrm{pt}$

FANAN, S.; NOVEMBRE, A.D.L.C. Condicionamento fisiológico de sementes de berinjela. Bragantia, v.66, n.4, p.675-683, 2007. http://www. scielo.br/scielo.php?script $=$ sci arttext\&pid=S0006-87052007000400018\&lng $=\mathrm{pt} \& \mathrm{nrm}=\mathrm{iso} \& \mathrm{tlng}=\mathrm{pt}$

GHASSEMI-GOLEZANI, K.; ESMAEILPOUR, B. The effect of salt priming on the performance of differentially matured cucumber (Cucumis sativus) seeds. Notulae Botanicae Horti Agrobotanici Cluj-Napoca, v.36, n.2, p.67-70, 2008.

HILHORST, H.W.M.; SMITT, A.I.; KARSSEN, C.M. Gibberellin-biosynthesis and sensitivity mediated stimulation of seed germination of Sisymbrium officinale by red light and nitrate. Physiologia Plantarum, v.67, n. 2, p.285-290, 1986.

HILLEL, D. Soil and water: physical principles and processes. New York: Academic, Preso, 1971. 288p.

LUNA, B.; MORENO, J.M. Light and nitrate effects on seed germination of Mediterranean plant species of several functional groups. Plant Ecology, v.203, n.1, p.123-135, 2009

MAGUIRE, J.D. Speed of germination: aid in selection and evaluation for seedling emergence and vigour. Crop Science, v.2, n.2, p.176-177, 1962.

MEDEIROS, M.A.; GRANGEIRO, L.C.; TORRES, S.B.; FREITAS, A.V.L. Maturação fisiológica de sementes de maxixe (Cucumis anguria L.). Revista Brasileira de Sementes, v.32, n.3, p.17-24, 2010. http://www.scielo.br/scielo. php?script=sci_arttext\&pid=S0101-31222010000300002\&lng=pt\&nrm=iso \&tlng $=\mathrm{pt}$

MICHEL, B.E.; KAUFMANN, M.R. The osmotic potential of polyethylene glycol 6000. Plant Physiology, v.51, p.914-916, 1973. http://www. plantphysiol.org/content/51/5/914.full.pdf + html

NASCIMENTO, W.M.; LIMA, L.B. Condicionamento osmótico de sementes de berinjela visando a germinação sob temperaturas baixas. Revista Brasileira de Sementes, v.30, n.2, p.224-227, 2008. http://www.scielo.br/scielo.php?script=sci_ arttext\&pid=S0101-31222008000200029\&lng=pt\&nrm=iso\&tlng=pt

PILL, W.G.; COLLINS, C.M.; GOLDBERGER, B.; GREGORY, N. Responses of non-primed or primed seeds of 'Marketmore 76' cucumber (Cucumis sativus L.) slurry coated with Trichoderma species to planting in growth media infested with Pythium aphanidermatum. Scientia Horticulturae, v.121, n.1, p.54-62, 2009. http:// riseofbiopesticides.com/files/BioWorks/Responses\%20of\%20cucumber $\% 20$ seeds $\% 20$ slurry $\% 20$ coated $\% 20$ with $\% 20$ Trichoderma.pdf

REIS, R.G.E.; GUIMARÃES, R.M.; VIEIRA, A.R.V.; GONÇALVES, N.R.; COSTA, V.H. Physiological quality of osmoprimed eggplant seeds. Ciência e Agrotecnologia, v.36, n.5, p.526-532, 2012. http://www.scielo.br/scielo. php?script=sci_arttext\&pid=S1413-70542012000500005\&lng=pt\&nrm=iso

ROVERI JOSÉ, S.C.B.; VIEIRA, M.G.G.C.; GUIMARÃES, R.M. Efeito da temperatura e do período de condicionamento osmótico na germinação e no vigor de sementes de pimentão. Revista Brasileira de Sementes, v.22, n.2, p.176-184, 2000

ROVERI JOSÉ, S.C.B.; VIEIRA, M.G.G.C.; GUIMARÃES, R.M.; RODRIGUES, R. Alterações fisiológicas e bioquímicas de pimentão submetidas ao osmocondicionamento, utilizando diferentes agentes osmóticos e meios de embebição. Revista Brasileira de Sementes, v.21, n.2, p.217-223, 1999.

SAINI, H.S.; BASSI, P.K; SPENCER, M.S. Seed germination in Chenopodium album L. relationship between nitrate and the effects of plant hormones. Plant Physiology, v.77, n.4, p.940-943, 1985. http://www. plantphysiol.org/content/77/4/940.full.pdf + html

SANTOS, M.C.A.; AROUCHA, E.M.M.; SOUZA, M.S.; SILVA, R.F.; SOUSA, P.A. Condicionamento osmótico de sementes. Caatinga, v.21, n.2, p.1-6, 2008.

SILVA, J.R.; TORRES, S.B.; MEDEIROS, M.A.A.; OLIVEIRA, I.R.S. Avaliação do potencial fisiológico de sementes de maxixe. Caatinga, v.21, n.4, p.68-71, 2008.

TRIGO, M.F.O.O.; NEDEL, J.L.; TRIGO, L.F.N. Condicionamento osmótico em sementes de cebola: I. Efeitos sobre a germinação. Scientia Agricola, v.56, n.4, p.1059-1067, 1999. http://www.scielo.br/scielo.php?script=sci arttext\&pid $=$ S0103-90161999000500007

VENKATASUBRAMANIAN, A.; UMARANI, R. Evaluation of seed priming methods to improve seed performance of tomato (Lycopersicon esculentum), egg plant (Solanum melongena) and chilli (Capsicum annum). Seed Science and Technology, v.35, p.487-493, 2007. 